\title{
Accounting Standards, Reporting Incentives, and Earnings Management
}

\author{
Xiaoxiao Song ${ }^{1} \&$ Jennifer L. Bannister ${ }^{2}$ \\ ${ }^{1}$ Assistant Professor Southern Illinois University Edwardsville School of Business Campus Box 1104 Edwardsville, \\ IL, USA \\ ${ }^{2}$ Assistant Professor University of Dallas Satish \& Yasmin Gupta College of Business 1845 E. Northgate Drive \\ Irving, USA \\ Correspondence: Jennifer L. Bannister, Assistant Professor University of Dallas Satish \& Yasmin Gupta College of \\ Business 1845 E. Northgate Drive Irving, USA. E-mail: jbannister@udallas.edu
}

Received: October 20, 2019

Accepted: April 11, 2020

Online Published: April 15, 2020

doi:10.5430/afr.v9n2p60

URL: https://doi.org/10.5430/afr.v9n2p60

\begin{abstract}
In this study, we examine which factor, firms' accounting standards or firms' reporting incentives, has a greater impact on firms' earnings management behavior. To answer this question, we utilize unique hand-collected data that consists of foreign firms cross-listed in the U.S. using U.S. GAAP. This interesting setting allows us to control for differing accounting standards and external monitoring from the SEC between foreign firms and their U.S. domestic counterparts. Therefore, if there is any observed difference in the level of firms' earnings management, that difference can be mainly attributed to firms' reporting incentives rather than firms' accounting standards. Our findings suggest that cross-listed foreign firms using U.S. GAAP exhibit more accruals-based and real activities earnings management relative to domestic firms. The results suggest that accounting standards, regulations, and enforcement is not enough to eliminate opportunistic reporting behavior. Firm incentives will still impact the magnitude of earnings management. This finding is particularly important given the hot debate regarding whether the U.S should adopt IFRS or not. No matter what accounting standards firms choose, U.S GAAP or IFRS, firms' earnings quality can still vary with differing reporting incentives.
\end{abstract}

Keywords: accounting standards, firms' reporting incentives, earnings management, cross-listed foreign firms

\section{Introduction}

A large amount of prior research examines the various factors that affect firms' earnings management behavior. Country-level institutional characteristics, accounting standards, and reporting incentives have all been shown to affect opportunistic reporting behavior to some degree. While prior research addresses the influence of these factors in various settings, it is often not easy to isolate the effects of each from one another, especially in international accounting or finance studies where firms use various accounting standards from different countries. However, it is often imperative to understand the individual role played by each factor. For example, as the Securities and Exchange Commission (SEC) considers the future of IFRS in the United States, understanding the role that accounting standards play in limiting earnings management could be beneficial in the decision-making process.

In this study, we investigate the role of accounting standards and reporting incentives in curbing the opportunistic reporting behavior of foreign firms who trade their stocks in the U.S. Foreign firms have been shown to exhibit lower earnings quality than U.S. firms, even after cross-listing in the United States (Lang, Raedy \& Wilson, 2006, among others). However, when these firms cross-list in the U.S., they can choose to file their financial statements using U.S. GAAP, IFRS, or a local GAAP reconciled to U.S. GAAP. Given that accounting standards usually play a role in earnings management, the higher or lower earnings quality between foreign and domestic firms can stem from different accounting standards, different reporting incentives, or a mix of both factors. To isolate these two factors from each other, we utilize a unique hand-collected sample that only contains foreign firms using U.S. GAAP and U.S. domestic firms. This interesting setting allows us to hold the accounting standards constant. Additionally, both groups of firms in the sample are held to similar regulations with the SEC. We argue that when the two groups share the same accounting standards and are monitored by the same government, their earnings quality is more likely to be driven by firms' reporting incentives. Therefore, any observed difference in the level of firms' earnings management can be mainly attributed to firms' reporting incentives rather than other factors. Prior research indicates that real earnings management often serves as an alternative for accruals-based earnings management, therefore, we compare 
both real and accruals-based earnings management for foreign and domestic firms in the U.S. If accruals-based earnings management is limited, firms may turn to real earnings management. However, firms can have a higher magnitude of both accrual-based and real activities earnings management if their overall reporting incentives are more aggressive.

Understanding the role of accounting standards in curbing firms' earnings management is particularly important as standard-setters in the U.S. decide whether to adopt IFRS for U.S. firms. In 2007, the SEC eliminated the required reconciliation to U.S. GAAP when foreign private issuers (FPI) file IFRS-compliant financial statements. This move indicates a growing acceptance of IFRS in the U.S. and a belief that the use of IFRS rather than U.S. GAAP does not significantly impair the quality of financial statements, at least for FPIs. However, if using different accounting standards is associated with varying reporting quality, then policy-setters have to be more careful about potential IFRS adoption since U.S. investors rely heavily on these statements to allocate their equity portfolios.

Using a hand-collected sample spanning from 2004 to 2015, we compare foreign firms using U.S GAAP and matched domestic firms in terms of their earnings quality. The OLS regression tests suggest that cross-listed foreign firms, compared to domestic firms, exhibit higher levels of accruals-based and real earnings management. We also divide the foreign firms in the sample according to the investor protection in their home countries. The results indicate that when foreign firms are from countries with strong investor protection, they engage in less accruals-based earnings management, but instead turn to real activities manipulations as a substitute. Overall, our findings show that cross-listing and using U.S. GAAP may not be enough to limit the earnings management of foreign firms to the level of U.S. domestic firms without the existence of strong investor protection in the home country.

This study makes several contributions. First, we offer empirical evidence regarding the impact of accounting standards on firms' earnings quality. This is particularly important now that the U.S. is considering allowing IFRS and prior studies have found that IFRS can increase or decrease accounting quality. The results of our study suggest that accounting standards, regulations, and enforcement alone cannot control earnings management levels. Firm incentives will still play a role in the level of earnings management. Hail et al. (2010) state that it is inappropriate to solely focus on accounting standards because reporting outcomes are determined by many more elements than accounting standards alone. They argue that accounting standards by themselves have limited ability to curb firms' opportunistic behaviors. Both IFRS and U.S. GAAP have discretion that can be used by managers. If IFRS has fewer requirements and lower quality, managers can maintain their reporting behavior by voluntarily following the U.S. GAAP standards. If IFRS has higher requirements and leads to better reporting quality, then managers might just adopt IFRS "in name" instead of improving their actual earnings quality. Either way, firms' reporting quality will be hardly affected by just changing their accounting standards. Our findings support this view by confirming that even when firms reporting in the U.S. use the same accounting standards, differing incentives can still result in different levels of earnings management. Our findings are important for U.S. investors who should not make investment decisions solely based on foreign firms' accounting standards. For regulatory bodies, such as the SEC and the FASB, our study provides evidence that even when firms reporting in the U.S. use the same accounting standards, differing incentives can still result in different levels of earnings management. When considering the future of IFRS and U.S. GAAP in the United States, standard-setters should consider that, given that both sets of standards are of high quality, a more consequential project might be an endeavor to align firm incentives with desired reporting outcomes. For example, rather than focusing solely on the accounting standards used by foreign firms that are cross-listing in the U.S., the SEC could consider regulating any number of internal corporate governance mechanisms that could improve firm reporting and shift incentives.

Second, our paper uses a unique setting where we can control for firms' accounting standards and external monitoring, so that we can isolate the effect of foreign cross-listed firms' and domestic firms' differing reporting incentives on earnings quality. Prior studies have found that, compared to U.S. domestic firms, foreign cross-listed firms have lower earnings quality (Lang et al. 2006). However, comparing all foreign cross-listed firms to domestic firms without controlling for different accounting standards may not be appropriate because prior studies have found accounting standards can be associated with reporting quality. Our design addresses this problem by comparing U.S. domestic firms that use U.S GAAP and foreign private issuers that use U.S. GAAP, so that we can control for confounding factors and provide a clearer setting to test the reporting incentive effect on earnings quality. Future studies can consider this type of sample when they compare foreign firms with U.S. domestic firms, or test earnings quality between IFRS and U.S. GAAP. 
Lastly, our findings provide additional evidence regarding the trade-off between accruals and real activities earnings management for both foreign and domestic firms. Foreign firms overall engage in higher discretionary accruals and real earnings management. One possible reason is that they have more opportunistic reporting incentives than U.S. domestic firms, which leads to more earnings management in total. However, when we only examine foreign cross-listed firms, results indicate that strong investor protection in their home countries can effectively mitigate the abnormal discretionary accruals. In this situation, foreign firms turn to higher real earnings management as a substitute. This finding pushes forward prior studies by showing the importance of country-level factors for firms' choices between real and accruals earnings management.

Lang et al. (2006) also compare cross-listed foreign firms and U.S firms in terms of their earnings quality. In their supplementary analyses, they employ foreign firms using U.S. GAAP. Our paper differs in several ways. First, we measure firms' earnings quality with the level of both accruals-based and real activities based earnings management. Lang et al. (2006) focus on other earnings properties, such as earnings smoothing, the tendency for small positive income, value relevance and loss recognition. Second, we extend the earnings quality measures to include real activities as well as accruals-based, and we test the trade-off between these two methods, which is not investigated in the Lang et al. study. Third, our sample size $(1,432)$ is much larger than theirs (200) and can provide stronger testing power. Fourth, given the current debate of IFRS adoption in the U.S, our paper carries more practical implications for policy makers, investors, and the SEC. In addition, many changes to U.S. GAAP and IFRS have occurred between the sample period used in Lang et al. (2006) and our sample period. For example, since the publication of Lang et al. (2006), the SEC has eliminated the reconciliation requirement for foreign private issuers using U.S. GAAP in 2007, potentially changing their reporting decisions.

\section{Literature Review and Hypotheses Development}

Over the past 50 years, the popularity of research surrounding earnings management has increased drastically. Beginning in the 1970s, scholars noticed that managers can choose accounting policies in order to manipulate or influence firms' reported earnings to serve an agenda. For example, Watts and Zimmerman (1978) state that firms can minimize political costs, such as labor union costs, by lowering reported earnings. In the 1980s, more research began investigating the incentives and techniques of earnings management. Holthausen (1981) finds that managers utilize various depreciation methods to achieve desired earnings results in order to meet bond covenants. Healy (1985) investigates managers' compensation contracts as a driver of earnings manipulation. Using empirical methods that involve splitting accruals into discretionary and non-discretionary, he concludes that managers use discretionary accruals as a tool to reach income levels necessary to receive their compensation bonuses. In a descriptive study, Schipper (1989) reviews several earnings management studies. She discusses the objective of earnings management and provides circumstances where earnings management is most likely to occur. In the 1990s, earnings management research continued with researchers examining the topic from various and numerous perspectives. Jones (1991) investigates whether managers decrease firms' income purposefully to reduce the import relief, introducing the well-known Jones's model to calculate expected normal accruals. Dechow et al. (1995) modified Jones's model by including the change in firms' receivables. Using randomly selected samples of 1,000 firm-year observations, they empirically test and compare the modified Jones model to other models and conclude that the modified model outperformed other models in detecting firms' earnings management practices. This model has become a staple of earnings management research when measuring firms' discretionary accruals. Other studies also investigate firms' earnings management incentives and consequences. Burgstahler and Dichev (1997) find evidence that the frequency of small positive income amounts is much higher than the frequency of small losses. This discontinuity around zero indicates that managers manipulate earnings to avoid negative income. Similarly, Degeorge et al. (1999) provide three thresholds at which managers have incentives to manage earnings, namely to report positive earnings, to beat last year's earnings benchmark, and to meet analysts' forecasts. Teoh et al. (1998) hypothesize that if managers choose to manipulate earnings to boost income for seasoned equity offerings, the performance of these firms will be worse than that of their peers who did not manage earnings. This is because accruals will reverse in the future, limiting the firms' ability to manage earnings long-term.

In the 2000s, two streams of earnings management literature developed, which are significant for our study. The first stream is introduced by Roychowdhury (2006) who expands prior literature, which primarily focused on accruals manipulation, by providing empirical evidence that managers also use real activities to manipulate earnings in order to avoid losses. The three indicators identified for real earnings management are operating cash flows, production costs, and discretionary expenditures. Applying Roychowdhury's (2006) real earnings management models, Cohen et al. (2008) examine firms' behavior before and after the Sarbanes Oxley Act. They notice that there is a trade-off between accruals' and real activities' earnings management by showing more (less) accruals (real activities) earnings 
management before the Act and less (more) accruals (real activities) earnings management after the Act. Similar results are also documented by Cohen and Zarowin (2010) and Zang (2012), and other scholars.

The second stream of earnings management literature critical to our study is earnings management behavior in countries outside of the United States. Prior research documents that firms' reporting quality varies across countries (Leuz et al. 2003). Leuz et al. (2003) suggest that this variation is related to institutional characteristics, specifically, the amount of investor protection. They argue that incentives to manage earnings as a means of misrepresenting firm performance arise from a conflict of interests between firm insiders and outsiders. When investor protection within a country is weak, insiders possess more private control benefits to lose and therefore, more incentive to obscure actual firm performance through earnings management. Leuz et al. measure the pervasiveness of earnings management within 31 countries and find that the U.S. represents the lowest level of earnings management among all of the countries. Bushman et al. (2004) also conduct an international study to find factors affecting firms' information transparency. They conclude that countries with advanced legal systems are correlated with higher information transparency between firms' inside managers and outside information users. Enomoto et al. (2015) extend Leuz et al. (2003) by examining both accruals and real activities using a multinational sample. They find evidence that in strong investor protection countries, firms engage in less accruals earnings management; however, they turn to real activities to achieve desired income instead.

Given the findings of Leuz et al. (2003) and Bushman et al. (2004), it seems likely that U.S. firms would exhibit less earnings management than their cross-listed counterparts; however, the act of cross-listing subjects these foreign firms to many of the same standards and regulations as U.S. domestic firms (Coffee 2002). Foreign cross-listed firms are commonly used as substitutes for U.S. domestic firms in prior studies, suggesting that they are anticipated to behave similarly (e.g. Kaya and Pillhofer 2013; Sun et al. 2011). Being subject to similar reporting requirements and oversight as U.S. firms may mean that the level of earnings management exhibited by cross-listed firms is closer to that of U.S. firms than that of firms in their home countries. In support of this, Lang et al. (2003) find that foreign firms cross-listed in the U.S. exhibit higher accounting quality than firms that are not cross-listed based on numerous proxies of accounting quality, including earnings management. This association between cross-listing and accounting quality is not observed when firms cross-list on other markets besides the U.S., suggesting that it is the unique environment of the U.S. markets that is related to the improved accounting quality of these firms. Additionally, results from Chang and Sun (2009) show that the monitoring ability of corporate governance mechanisms on foreign firms' earnings quality is stronger in the post-SOX period.

Despite these findings, research suggests that there are limitations to the ability of U.S. enforcement and regulations to restrain foreign cross-listed firms as much as U.S. firms, leading to differences in the incentives of the two groups of firms. Although the filings of cross-listed firms are subject to the same SEC oversight as U.S. firms, Siegel (2005) finds that in reality, the SEC rarely pursues litigation against foreign firms and is often unsuccessful when it does. Additionally, litigation brought by minority shareholders against foreign cross-listed firms rarely results in anything more than a minor settlement as a result of institutional obstacles (Siegel 2005).

In addition to enforcement and other institutional characteristics, accounting standards are also shown to be associated with earnings management. For example, accruals-based earnings management is shown to be more prevalent when standards are less precise (Ewert and Wagenhofer 2005; Trompeter 1994). As countries have switched from local accounting standards to IFRS, a host of research has studied the effect of this change on earnings management. This research shows that a change in accounting standards is often associated with a change in the level of earnings management, supporting the idea that accounting standards play a role in deterring opportunistic reporting behavior (e.g. Chen et al. 2010; Ahmed et al. 2013; Barth et al. 2008). Despite this, as argued by Hail et al. (2010), there are many other factors besides accounting standards that will influence firms' reporting quality. For example, in the U.S., all domestic firms follow U.S. GAAP, but they demonstrate various levels of earnings quality. Houmes and Skantz (2010) find that when managers have equity in their compensation plans, they have stronger incentive to report profits for their own benefits and therefore are more likely to "cook the books". Similar findings are illustrated in international accounting and finance studies that find firms with different reporting incentives from different countries show heterogeneous reporting quality (Ball et al. 2000, 2003; Burgstahler et al. 2006). Based on the literature discussed above, it is unclear whether foreign cross-listed firms that file U.S. GAAP financial statements will engage in any more earnings management than U.S. domestic firms. While prior research shows that the level of earnings management is low in the U.S. compared to other countries, firms that cross list in the U.S. "bond" themselves by voluntarily subjecting themselves to the regulations and enforcement of the U.S. Despite this bonding; however, the earnings quality of foreign cross-listed firms overall is still lower than that of U.S. firms. Although accounting standards are shown to be correlated with earnings management, it is unclear whether applying 
U.S. GAAP is enough to limit the earnings management behavior of cross-listed firms to the same level as domestic firms. Therefore, Hypothesis 1 is stated in the null form.

Hypothesis 1: There is no difference in the level of accruals-based earnings management for foreign firms cross-listed in the U.S. that use U.S. GAAP and U.S. domestic firms.

When the ability of firms using accruals-based earnings management to manipulate earnings is limited, prior studies have documented that they will often manipulate real activities to manage earnings instead (e.g. Ho et al. 2015; Ipino and Parbonetti 2017). Based on this, if there is a difference in the level of accruals-based earnings management for the two groups of firms, there may also be a difference in the level of real activities earnings management. However, if the two groups exhibit a similar level of accruals-based earnings management, there may not be a difference in real earnings management either. Therefore, the following hypothesis is stated in the null form.

Hypothesis 2: There is no difference in the level of real earnings management for foreign firms cross-listed in the U.S. that use U.S. GAAP and U.S. domestic firms.

\section{Methodology}

We utilize a matched-sample of foreign cross-listed firms using U.S. GAAP and U.S. domestic firms in order to compare the magnitude of earnings management by these two groups of firms. The following model is estimated using OLS regression:

$$
E M_{i t}=\beta_{0}+\beta_{1} \text { FOREIGN }_{i t}+\beta_{2} \text { SIZE }_{i t}+\beta_{3} \text { BtoM }_{i t}+\beta_{4} R O A_{i t}+\beta_{5} L E V_{i t}+\beta_{6} B I G 4_{i t}+\text { Industry Dummies }+ \text { Year Dummies }
$$

$+\varepsilon_{i t}$

Equation 1 is first estimated for accruals-based earnings management. The equation is estimated a second time with $E M$ defined as real earnings management. Our coefficient of interest is $\beta_{l}$, the coefficient on FOREIGN. A positive coefficient suggests that foreign firms using U.S. GAAP engage in more earnings management than domestic firms in the U.S. The remaining variables control for other factors found to affect firms' earnings quality in prior research. Industry dummies and year dummies are also used. Specific definitions of each variable are as follows:

$E M_{i t}=$ The level of either a firm's abnormal discretionary accruals (ACC_EM) or the real activities management (REAL_EM).

FOREIGN $_{i t}=$ An indicator variable with the value of one if the headquarters of a firm is outside of the U.S. and zero otherwise (Compustat $L O C$ )

$S I Z E_{i t}=$ Logarithm of a firm's total assets (Compustat $\left.A T\right)$

$B t o M_{i t}=$ A firm's book-to-market ratio (Compustat $C E Q /\left(C S H O * P R C C \_F\right)$ )

$R O A_{i t}=$ A firm's return on prior year's assets (Compustat $\left.I B / A T_{t-1}\right)$

$L E V_{i t}=$ A firm's leverage ratio (Compustat $\left.(D L C+D L T T) / A T\right)$

$B I G 4_{i t}=$ An indicator variable with the value of one if a firm is audited by the Big 4 firms, and zero otherwise (Compustat $A U$ )

When testing the level of accruals-based earnings management, $E M_{i t}$ is defined as the level of abnormal discretionary accruals (ACC_EM). We follow the modified Jones model (1995) to separate a firm's total discretionary accruals into normal and abnormal components based on the expected value. A higher abnormal discretionary value indicates that the firm uses more discretionary accruals to manage earnings.

$$
\text { TAccruals }_{i t} / T A_{i t-1}=\eta_{0}+\eta_{1}\left(1 / T A_{i t-1)}+\eta_{2} \Delta R e v_{i t} / T A_{i t-1}+\eta_{3}\left(P P E_{i t} / T A_{i t-1}\right)+\varepsilon_{i t}\right.
$$

Where;

TAccruals $=$ Total accruals, which are the difference between earnings before extraordinary items (Compustat $I B C$ ) and cash flow from operations (CFO)

$T A=$ Total assets $($ Compustat $A T)$

$\triangle R e v=$ Change in sales revenue (Compustat $S A L E)$ over two years

$P P T=$ Gross Property, Plant and Equipment (Compustat PPEGT)

We ran equation (2) separately for each 2-digit SIC industry and year with at least ten observations. The estimated coefficients are used to calculate firm $i$ 's normal or expected accruals. The abnormal discretionary accruals $\left(A C C_{-} E M\right)$ are calculated as firm $i$ 's actual total accruals minus the normal accruals. 
When using the equation to test real earnings management, $E M_{i t}$ is defined as the aggregated total amount of the three components of real activities management as stated by Roychowdhury (2006), which are abnormal cash flow from operations $(C F O)$, abnormal production costs (Prod), and abnormal discretionary expenses (Exp). A higher value indicates that firms are more likely to manipulate earnings by real activities. The following three equations are used to measure the three components.

$C F O_{i t} / T A_{i t-1}=\delta_{1}\left(1 / T A_{i t-1}\right)+\delta_{2}\left(S A L E_{i t} / T A_{i t-1}\right)+\delta_{3} \Delta S A L E_{i t} / T A_{i t-1}+\varepsilon_{i t}$

$\operatorname{Prod}_{i t} / T A_{i t-1}=\delta_{1}\left(1 / T A_{i t-1}\right)+\delta_{2}\left(S A L E_{i t} / T A_{i t-1}\right)+\delta_{3} \Delta S A L E_{i t} / T A_{i t-1}+\delta_{4} \Delta S A L E_{i t-1} / T A_{i t-1}+\varepsilon_{i t}$

$\operatorname{Exp}_{i l} / T A_{i t-1}=\delta_{1}\left(1 / T A_{i t-1}\right)+\delta_{2}\left(S A L E_{i t-1} / T A_{i t-1}\right)+\varepsilon_{i t}$

Where;

$C F O=$ Cash flow from operations (Compustat $(O A N C F-X I D O C))$

$S A L E=$ Sales revenue (Compustat SALE)

Prod $=$ Production costs, calculated as the total of cost of goods sold (Compustat COGS) and the change of inventories (Compustat INVT)

Exp $=$ Discretionary expenses, calculated as the total of advertising expenses, R\&D expenses, and SG\&A expenses (Compustat $X A D+X R D+X S G A)$

We ran equation (3), equation (4) and equation (5) separately for each 2-digit SIC industry and year with at least ten observations. The estimated coefficients are used to calculate firm $i$ 's normal real activities (cash flow from operations, production costs, and discretionary expenses). The abnormal real activities are calculated as firm $i$ 's actual real activities minus the normal real activities.

We then use a single aggregated measure, $R E A L_{-} E M$, of the three components (after adjusting abnormal cash flow from operations and abnormal discretionary expenses by multiplying by negative one so that a larger amount indicates more earnings management) as the total level of firms' real activities manipulation.

\section{Data and Descriptive Statistics}

Our sample period spans from 2004 to 2015. We obtained foreign firms listed on the three major exchange centers from the SEC website. We then searched each firm's annual report to hand collect their accounting standards (IFRS, U.S. GAAP or local standards). We only kept foreign firms using U.S.GAAP since the focus of our study is on firms' reporting incentives after controlling for firms' accounting standards. We delete firms from financial and other regulated industries, since their earnings behavior may differ. Any firms without the necessary variables to estimate Equation 1 to 5 are also eliminated. We match each foreign firm with a corresponding U.S. domestic firm based on the closest propensity score which is calculated by regressing whether a firm is foreign or domestic on firms' four characteristics (size, book to market ratio, ROA, and leverage). The final matched sample consists of 1,432 firm-year observations, or 716 pairs.

The detailed sample distribution is presented in Table 1. Specifically, Panel A shows that the number of observations are fairly consistent across the years. Panel B shows the sample distribution by the location of the firms' headquarters. Israel (ISR) and China (CHN) have the highest representation in the sample. Canadian (CAD) firms in the sample are limited, since most Canadian firms opt to use IFRS or Canadian GAAP.

Table 1. Sample Distribution by Year and Headquarters Location

\begin{tabular}{cccccc}
\hline \multicolumn{5}{c}{ Panel A: Sample Distribution by Year } \\
\hline Year & Frequency & Percent & Year & Frequency & Percent \\
\hline 2004 & 112 & 7.82 & 2010 & 118 & 8.24 \\
2005 & 108 & 7.54 & 2011 & 102 & 7.12 \\
2006 & 116 & 8.1 & 2012 & 114 & 7.96 \\
2007 & 120 & 8.38 & 2013 & 142 & 9.92 \\
2008 & 116 & 8.1 & 2014 & 134 & 9.36 \\
2009 & 130 & 9.08 & 2015 & 120 & 8.38 \\
\hline
\end{tabular}




\begin{tabular}{cccccc}
\hline \multicolumn{6}{c}{ Panel B: Sample Distribution by Headquarters Location } \\
\hline Country & Frequency & Percent & Country & Frequency & Percent \\
\hline AUS & 1 & 0.07 & HKG & 53 & 3.7 \\
BHS & 2 & 0.14 & IND & 2 & 0.14 \\
BMU & 6 & 0.42 & IRL & 12 & 0.84 \\
BRA & 4 & 0.28 & ISR & 215 & 15.01 \\
CAN & 28 & 1.96 & JPN & 87 & 6.08 \\
CHE & 16 & 1.12 & KOR & 13 & 0.91 \\
CHN & 194 & 13.55 & NLD & 22 & 1.54 \\
CYM & 12 & 0.84 & RUS & 3 & 0.21 \\
DEU & 5 & 0.35 & SGP & 4 & 0.28 \\
FRA & 16 & 1.12 & TWN & 19 & 1.33 \\
GBR & 2 & 0.14 & USA & 716 & 50
\end{tabular}

Table 2 provides the descriptive statistics for each variable. We separate the U.S. firms from foreign cross-listed firms in order to compare the differences in their mean (t-statistics) and median (z-statistics).

Table 2. Descriptive Statistics

\begin{tabular}{ccccccccccc}
\hline & \multicolumn{4}{c}{ U.S. Firms } & \multicolumn{3}{c}{ Foreign Firms } & \multicolumn{2}{c}{ Differences } \\
Variable & $N$ & Mean & Median & $\begin{array}{c}\text { Std } \\
\text { Dev }\end{array}$ & $N$ & Mean & Median & $\begin{array}{c}\text { Std } \\
\text { Dev }\end{array}$ & t-Statistics & $z$-Statistics \\
\hline ACC_EM & 716 & -0.011 & -0.004 & 0.082 & 716 & 0.011 & 0.020 & 0.085 & $<0.0001$ & $<0.0001$ \\
REAL_EM & 716 & -0.61 & -0.584 & 0.431 & 716 & -0.448 & -0.373 & 0.400 & $<0.0001$ & $<0.0001$ \\
SIZE & 716 & 6.77 & 6.697 & 2.214 & 716 & 6.352 & 6.051 & 2.054 & 0.0002 & $<0.0001$ \\
BtoM & 716 & 0.506 & 0.384 & 0.437 & 716 & 0.749 & 0.597 & 0.599 & $<0.0001$ & $<0.0001$ \\
ROA & 716 & 0.020 & 0.045 & 0.140 & 716 & 0.022 & 0.030 & 0.142 & 0.841 & $<0.0001$ \\
LEV & 716 & 0.127 & 0.066 & 0.157 & 716 & 0.141 & 0.085 & 0.163 & 0.099 & 0.342 \\
BIG4 & 716 & 0.784 & 1.000 & 0.412 & 716 & 0.785 & 1.000 & 0.411 & 0.949 & 0.949 \\
\hline
\end{tabular}

Based on the descriptive statistics, foreign cross-listed firms who use U.S. GAAP show a significantly higher magnitude of accruals-based earnings management (ACC_EM) than U.S. domestic firms ( 0.011 vs. -0.011$)$. They also use more real activities to manage earnings (REAL_EM) (-0.448 vs. -0.61). Both of these differences are significant at the $1 \%$ level in terms of the mean value and the median value. Additionally, the U.S. firms and foreign firms differ in the control variables as well. Cross-listed firms are smaller (6.352 vs. 6.77) and have a higher book to market ratio (0.749 vs. 0.506) than U.S. firms. However, both groups have similar leverage level (0.141 vs. 0.127) and the use of Big 4 auditors (0.785 vs. 0.784).

Table 3 provides the Pearson correlation coefficients for all variables. Our two measures of firms' earnings management, $A C C \_E M$ (accruals-based) and $R E A L \_E M$ (real activities), are both significantly and positively related to whether a firm is a foreign cross-listed firm or a U.S. domestic firm (FOREIGN). This suggests that foreign firms exhibit more accruals-based and real earnings management than domestic firms; however, these results may not hold after controlling for other variables. 
Table 3. Pearson Correlation Coefficients

\begin{tabular}{ccccccccc}
\hline & FOREIGN & ACC_EM & REAL_EM & SIZE & BtoM & ROA & LEV & BIG4 \\
\hline FOREIGN & 1 & & & & & & & \\
ACC_EM & 0.1325 & 1 & & & & & \\
& $(<0.0001)$ & & & & & & & \\
REAL_EM & 0.1975 & 0.2193 & 1 & & & & \\
& $(<0.0001)$ & $(<0.0001)$ & & & & & \\
SIZE & -0.0988 & 0.0543 & 0.1021 & 1 & & & \\
& $(-0.0002)$ & $(-0.0401)$ & $(-0.0001)$ & & & & \\
BtoM & 0.2255 & 0.1061 & 0.369 & -0.2233 & 1 & & \\
& $(<0.0001)$ & $(<0.0001)$ & $(<0.0001)$ & $(<0.0001)$ & & & \\
ROA & 0.0053 & 0.4171 & -0.2253 & 0.3631 & -0.2474 & 1 & \\
& $(-0.841)$ & $(<0.0001)$ & $(<0.0001)$ & $(<0.0001)$ & $(<0.0001)$ & & \\
LEV & 0.0435 & -0.0137 & 0.2613 & 0.2924 & -0.0627 & -0.0592 & 1 & \\
& $(-0.0998)$ & $(-0.6053)$ & $(<0.0001)$ & $(<0.0001)$ & $(-0.0176)$ & $(-0.0251)$ & & \\
& 0.0017 & 0.0098 & -0.0617 & 0.4119 & 0.1146 & 0.1215 & -0.1645 & 1 \\
BIG4 & $(-0.9488)$ & $(-0.7112)$ & $(-0.0196)$ & $(<0.0001)$ & $(<0.0001)$ & $(<0.0001)$ & $(<0.0001)$ & \\
\hline
\end{tabular}

\section{Results}

We report the results for Hypothesis 1 in Table 4 . The coefficient of interest is $\beta_{1}$, which is significantly positive at the $1 \%$ level. Therefore, even when foreign firms apply the same accounting standards (U.S. GAAP) and are under the same supervision from the SEC by cross-listing in the major stock exchanges, these foreign firms are more likely to adjust their accruals estimation and manage earnings relative to their U.S. counterparts. This significant difference can be mainly attributed to the differing reporting incentives in these two groups since we control for accounting standards and firm-level characteristics by including various control variables.

Table 4. OLS Regression Results for Test of Hypothesis 1

\begin{tabular}{|c|c|}
\hline Variable & Coefficient \\
\hline FOREIGN & $\begin{array}{c}0.0119 * * * \\
(2.94)\end{array}$ \\
\hline SIZE & $\begin{array}{c}-0.0044 * * * \\
(-3.68)\end{array}$ \\
\hline BtoM & $\begin{array}{c}0.0320 * * * \\
(7.52)\end{array}$ \\
\hline ROA & $\begin{array}{c}0.3032 * * * \\
(19.43)\end{array}$ \\
\hline LEV & $\begin{array}{c}0.0194 \\
(1.43)\end{array}$ \\
\hline BIG4 & $\begin{array}{l}0.0038 \\
(0.72)\end{array}$ \\
\hline Intercept & $\begin{array}{c}0.0059 \\
(0.28)\end{array}$ \\
\hline Year-fixed & $\mathrm{Y}$ \\
\hline Industry-fixed & $\mathrm{Y}$ \\
\hline R-square & 0.2536 \\
\hline Obs. & 1,432 \\
\hline
\end{tabular}

We then test the other tool of earnings management, manipulating real activities. The results are presented in Table 5 . Foreign firms might use less real activities to manage their earnings since they can utilize higher accrual-based 
manipulation as shown in Table 4, or foreign firms could still have more real earnings management besides the high discretionary accruals since they have more opportunistic reporting incentives. The significantly positive coefficient on the dummy variable FOREIGN indicates that foreign firms have more earnings management in total by applying both discretionary accruals and abnormal real transactions. The coefficients on other control variables are consistent with prior findings.

Table 5. OLS Regression Results for Test of Hypothesis 2

\begin{tabular}{cc}
\hline Variable & Coefficient \\
\hline FOREIGN & $0.1233 * * *$ \\
SIZE & $(6.75)$ \\
& $0.0384 * * *$ \\
BtoM & $(7.05)$ \\
& $0.2305 * * *$ \\
ROA & $(12.02)$ \\
& $-0.6641 * * *$ \\
LEV & $(-9.44)$ \\
& $0.3992 * * *$ \\
BIG4 & $(6.51)$ \\
& $-0.0799 * * *$ \\
Intercept & $(-3.31)$ \\
& $-0.6854 * * *$ \\
Year-fixed & $(-7.14)$ \\
Industry-fixed & $\mathrm{Y}$ \\
R-square & $\mathrm{Y}$ \\
Obs. & 0.4025 \\
\end{tabular}

\section{Additional Analyses}

A large amount of prior research finds that institutional characteristics play a major role in limiting firms' opportunistic earnings. Although cross-listed firms have voluntarily subjected themselves to the strict requirements of the U.S., their home country factors most likely still influence their reporting behaviors. In fact, the SEC often depends on local infrastructure for assistance in enforcement efforts in the home countries. Therefore, any mitigating effect of cross-listing on earnings management is most likely stronger if the home country has a developed legal system or strong enforcement power to protect investors' interest. In order to test whether home countries' investor protection levels affect foreign firms' earnings management in the U.S., we separate foreign firms into strong and low levels of investor protection based on the countries' anti-self-dealing index. A dummy variable "STRONG" is created if firm $i$ 's home country has a strong investor protection index. We re-test Equation 1 and present our findings in Table 6 .

The binary variable "STRONG" is our variable of interest. The coefficient is significantly negative at the $1 \%$ level, meaning that when the home countries have strong investor protection, foreign firms engage in less discretionary accruals when they cross-list in the U.S. This finding supports the Leuz et al. (2003) study that the level of firms' earnings quality is positively associated with countries' investor protection levels. Our result suggests that the institutional characteristics not only influence firms' reporting behavior, but also mitigate their opportunistic incentives even when firms have cross-listed shares in the U.S. 
Table 6. Accruals-Based Earnings Management for Foreign Firms

\begin{tabular}{|c|c|}
\hline Variable & Coefficient \\
\hline \multirow[t]{2}{*}{ STRONG } & $-0.0205 * * *$ \\
\hline & $(-2.99)$ \\
\hline \multirow[t]{2}{*}{ SIZE } & $-0.0055 * * *$ \\
\hline & $(-2.98)$ \\
\hline \multirow[t]{2}{*}{ BtoM } & $0.0314 * * *$ \\
\hline & $(5.43)$ \\
\hline \multirow[t]{2}{*}{$R O A$} & $0.2810 * * *$ \\
\hline & $(11.85)$ \\
\hline \multirow[t]{2}{*}{$L E V$} & -0.0077 \\
\hline & $(-0.38)$ \\
\hline \multirow[t]{2}{*}{ BIG4 } & 0.0011 \\
\hline & $(0.14)$ \\
\hline \multirow[t]{2}{*}{ Intercept } & 0.0358 \\
\hline & $(1.01)$ \\
\hline Year-fixed & $\mathrm{Y}$ \\
\hline Industry-fixed & $\mathrm{Y}$ \\
\hline R-square & 0.2263 \\
\hline Obs. & 696 \\
\hline
\end{tabular}

Although strong investor protection in home countries can mitigate foreign firms' discretionary accruals, it may not necessarily have a similar effect on real activities earnings management. As previously stated, when firms are limited with accruals-based earnings management, they may turn to real activities as a substitute. Results from Table 7 indicate that while foreign firms from countries with strong investor protection have lower discretionary accruals, they substitute with a higher degree of real transaction manipulation. The significantly positive coefficient on "STRONG" suggests that foreign firms from countries with strong investor protection are more likely to utilize real activities manipulation when they are inhibited from using accrual-based earnings management. These results support the substitution effect of real earnings management. Therefore, although strong investor protection is found to be effective in mitigating discretionary accruals, foreign firms turn to the manipulation of real activities instead due to their opportunistic reporting incentives. 
Table 7. Real Activities Earnings Management for Foreign Firms

\begin{tabular}{cc}
\hline Variable & Coefficient \\
\hline STRONG & $0.1005 * * *$ \\
SIZE & $(3.59)$ \\
BtoM & $0.0346 * * *$ \\
& $(4.60)$ \\
ROA & $0.1848 * * *$ \\
& $(7.81)$ \\
LEV & $-0.8689 * * *$ \\
& $(-8.97)$ \\
BIG4 & $0.2550 * * *$ \\
& $(3.09)$ \\
Intercept & $-0.0539 *$ \\
& $(-1.65)$ \\
Year-fixed & $-0.5949 * * *$ \\
Industry-fixed & $(-4.11)$ \\
R-square & $\mathrm{Y}$ \\
Obs. & $\mathrm{Y}$ \\
& 0.4120 \\
& 696 \\
&
\end{tabular}

\section{Conclusion}

In this paper, we examine the effect of accounting standards and firms' reporting incentives on firms' accruals based and real activities based earnings management. We focus on a comparison of foreign firms cross-listed in the U.S. that use U.S. GAAP and U.S. domestic firms. Prior studies, such as Lang et al. (2006), have found that cross listed foreign firms' reconciled earnings exhibit a lower reporting quality than the U.S. domestic firms. However, research regarding earnings management of foreign firms using U.S. GAAP and U.S. domestic firms is scarce. We fill this gap by utilizing a unique setting where both foreign firms and the U.S. domestic firms apply U.S. GAAP as their financial accounting standards and are both subject to SEC regulations and enforcement. By comparing the earnings management of these two groups after controlling for their accounting standards, we can separate the effect of firms' reporting incentives from the effect of accounting standards on opportunistic reporting behavior. We find that foreign firms using U.S. GAAP still exhibit a higher level of accruals-based and real activities earnings management. Further analyses show that foreign firms domiciled in strong investor protection countries (proxied by the anti-self-dealing index) exhibit higher real activities management to substitute their lower accruals management. Overall, the results of our paper support the idea that accounting standards alone are not enough to mitigate opportunistic reporting, rather, the level of earnings management will also be closely related to firms' reporting incentives. This implies that, whether the U.S. continues to use U.S. GAAP or allows IFRS, accounting quality may remain constant regardless.

In this study, we focus on accounting standards as a means to mitigate earnings management; however, numerous other channels can affect earnings quality. One example is the corporate governance within firms. Prior studies, such as Giroud and Mueller (2011), Coles et al. (2017), Li (2014), Core and Guay (1999), and Li et al. (2018) have demonstrated that firms' corporate governance is related to equity prices, firm risk, firm value, the optimal equity incentive, and firms' inside debt. Given that U.S.-listed foreign firms are from different countries with varying levels of corporate governance, it would be interesting to examine how various corporate governance mechanisms interact with firms' earnings management. Another avenue for further studies is an investigation of the role of foreign firms' CSR on managers' reporting behavior ( $\mathrm{Li}$ and Thibodeau 2019). We leave these avenues open for other scholars interested in earnings management behavior in an international context. 


\section{References}

Ahmed, A. S., Neel, M. \& Wang, D. (2013). Does mandatory adoption of IFRS improve accounting quality? Preliminary evidence. Contemporary Accounting Research, 30(4), 1344-1372. https://doi.org/10.1111/j.1911-3846.2012.01193.x

Ball, R., Kothari, S.P. \& Robin, A. (2000). The effect of international institutional factors on properties of accounting earnings. Journal of Accounting and Economics, 29, 1-51. https://doi.org/10.2139/ssrn.176989

Ball, R., Robin, A. \& Wu, J. S. (2003). Incentives versus standards: properties of accounting income in four East Asian countries. Journal of Accounting and Economics, 36(1), 235-270. https://doi.org/10.1016/j.jacceco.2003.10.003

Ball, R., Li, X. \& Shivakumar, L. (2015). Contractibility and transparency of financial statement information prepared under IFRS: Evidence from debt contracts around IFRS adoption. Journal of Accounting Research, 53(5), 915-963. https://doi.org/10.1111/1475-679X.12095

Barth, M. E., Landsman, W. R. \& Lang, M. (2008). International Accounting Standards and accounting quality. Journal of Accounting Research, 46, 467-498. https://doi.org/10.1111/j.1475-679X.2008.00287.x

Burgstahler, D. \& Dichev, I. (1997). Earnings management to avoid earnings decreases and losses. Journal of accounting and economics, 24(1), 99-126. https://doi.org/10.1016/S0165-4101(97)00017-7

Burgstahler, D., Hail, L. \& Leuz, C. (2006). The importance of reporting incentives: earnings management in European private and public firms. The Accounting Review, 81(5), 983-1016. https://doi.org/10.2308/accr.2006.81.5.983

Chang, J. \& Sun, H. (2009). Cross-listed foreign firms' earnings informativeness, earnings management, and disclosure of corporate governance information under SOX. The International Journal of Accounting, 44, 1-32. https://doi.org/10.1016/j.intacc.2008.12.004

Chen, H., Tang, Q., Jiang, Y. \& Lin, Z. (2010). The role of international financial reporting standards in accounting quality: Evidence from the European Union. Journal of International Financial Management and Accounting, 21(3), 220-278. https://doi.org/10.1111/j.1467-646X.2010.01041.x

Coffee, J. (2002). Racing towards the top? The impact of cross-listing and stock market competition on international corporate governance. Columbia Law Review, 102(7), 1757-1831. https://doi.org/10.2307/1123661

Cohen, D. A., Dey, A. \& Lys, T. Z. (2008). Real and accrual-based earnings management in the pre-and post Sarbanes-Oxley periods. The accounting review, 83(3), 757-787.

Cohen, D. A. \& Zarowin, P. (2010). Accrual-based and real earnings management activities around seasoned equity offerings. Journal of accounting and Economics, 50(1), 2-19. https://doi.org/10.1016/j.jacceco.2010.01.002

Dechow, P. M., Sloan, R. G. \& Sweeney, A. P. (1995). Detecting earnings management. Accounting review, 193-225.

Degeorge, F., Patel, J. \& Zeckhauser, R. (1999). Earnings management to exceed thresholds. The Journal of Business, 72(1), 1-33. https://doi.org/10.1086/209601

Enomoto, M., Kimura, F. \& Yamaguchi, T. (2015). Accrual-based and real earnings management: An international comparison for investor protection. Journal of Contemporary Accounting \& Economics, 11(3), 183-198. https://doi.org/10.1016/j.jcae.2015.07.001

Ewert, R. \& Wagenhofer, A. (2005). Economic effects of tightening accounting standards to restrict earnings management. The Accounting Review, 43, 101-124. https://doi.org/10.2308/accr.2005.80.4.1101

Hail, L., Leuz, C. \& Wysocki, P. (2010). Global accounting convergence and the potential adoption of IFRS by the US (Part I): Conceptual underpinnings and economic analysis. Accounting Horizons, 24(3), 355-394. https://doi.org/10.2308/acch.2010.24.3.355

Healy, P. M. (1985). The effects of bonus schemes on accounting decisions. Journal of Accounting and Economics, 7, 85-107.

Ho, L. C. J., Liao, Q. \& Taylor, M. (2015). Real and accrual-based earnings management in the pre-and post-IFRS periods: Evidence from China. Journal of International Financial Management and Accounting, 26(3), 294-335. https://doi.org/10.1111/jifm.12030 
Holthausen, R. W. (1981). Evidence on the effect of bond covenants and management compensation contracts on the choice of accounting techniques: The case of the depreciation switch-back. Journal of Accounting and Economics, 3(1), 73-109. https://doi.org/10.1016/0165-4101(81)90035-5

Ipino, E. \& Parbonetti, A. (2017). Mandatory IFRS adoption: the trade-off between accrual-based and real earnings management. Accounting and Business Research, 47(1), 91-121. https://doi.org/10.1080/00014788.2016.1238293

Jones, J. J. (1991). Earnings management during import relief investigations. Journal of accounting research, 29(2), 193-228. https://doi.org/10.2307/2491047

Kaya, D. \& Pillhofer, J. A. (2013). Potential adoption of IFRS by the United States: a critical view. Accounting Horizons, 27(2), 271-299. https://doi.org/10.2308/acch-50423

Lang, M., Ready, J. \& Wilson, W. (2006). Earnings management and cross listing: Are reconciled earnings comparable to U.S. earnings? Journal of Accounting and Economics, 42(1), 255-283. https://doi.org/10.1016/j.jacceco.2006.04.005

Lang, M., Ready, J. \& Yetman, M. (2003). How representative are firms that are cross-listed in the United States? An analysis of accounting quality. Journal of Accounting Research, 41(2), 363-386. https://doi.org/10.1111/1475-679X.00108

Leuz, C., Nanda, D. \& Wysocki, P. (2003). Earnings management and investor protection: an international comparison. Journal of Financial Economics, 69, 505-527. https://doi.org/10.1016/S0304-405X(03)00121-1

Roychowdhury, S. (2006). Earnings management through real activities manipulation. Journal of accounting and economics, 42(3), 335-370. https://doi.org/10.1016/j.jacceco.2006.01.002

Schipper, K. (1989). Commentary on earnings management. Accounting horizons, 3(4), 91-102.

Siegel, J, (2005). Can foreign firms bond themselves effectively by submitting to U.S. law? Journal of Financial Economics, 75, 319-359. https://doi.org/10.1016/j.jfineco.2004.02.001

Sun, J., Cahan, S.F. \& Emanuel,D. (2011). How would the mandatory adoption of IFRS affect the earnings quality of U.S. firms? Evidence from cross-listed firms in the U.S. Accounting Horizons, 25, 837-860. https://doi.org/10.2308/acch-50049

Teoh, S. H., Welch, I. \& Wong, T. J. (1998). Earnings management and the underperformance of seasoned equity offerings. Journal of Financial economics, 50(1), 63-99. https://doi.org/10.1016/S0304-405X(98)00032-4

Trompeter, G. (1994). The effect of partner compensation schemes and Generally Accepted Accounting Principles on audit partner judgment. Auditing: A Journal of Practice and Theory, 13, 56-71.

Watts, R. L. \& Zimmerman, J. L. (1978). Towards a positive theory of the determination of accounting standards. Accounting review, 112-134.

Zang, A. Y. (2012). Evidence on the trade-off between real activities manipulation and accrual-based earnings management. The accounting review, 87(2), 675-703. https://doi.org/10.2308/accr-10196 